Acta Horticulturae et Regiotecturae 2

Nitra, Slovaca Universitas Agriculturae Nitriae, 2015, pp. 30-34

\title{
EVALUATION OF EXCHANGE REACTION IN SOIL IN SEDIMENTS OF A REGION AFFECTED BY ANTHROPOGENIC ACTIVITY IN RELATION TO THE TIME AND TO THE SELECTED POTENTIALLY TOXIC ELEMENTS
}

\author{
Jana URMINSKÁ, * Boris VÁCLAV, Peter ONDRIŠÍK \\ Slovak University of Agriculture in Nitra, Slovak Republic
}

\begin{abstract}
The aim of this study was to analyse sediments of the selected water reservoirs of Piargs group. Secondly, our purpose was to determine values of exchange reactions in soil of these sediments during the period from 2001 to 2010 and to evaluate environmental hazards caused by the selected potentially toxic elements affected by $\mathrm{pH}$. Based on the results gained by analysis we aim to determine the correlation and statistical significance of dependencies of the analysed environmental parameters. Two different methods, the flow electrochemical method and the atomic absorption spectrometric method have been used to analyse the content of potentially toxic chemical elements in leachate. The analysis of leachate samples, in order to find out the values of exchange reactions in soil, was carried out by potentiometry. Ascertained values of exchange reactions in soil ranged from 5.6 to 7.2. According to the calculated indices of dependencies, the development of $\mathrm{pH} / \mathrm{KCl}$ values can be evaluated as moderately dynamic. The calculated indices of the Spearman's correlation coefficient for exchange reactions in soil demonstrate statistically significant dependence, especially for zinc and cadmium.
\end{abstract}

Keywords: analysis of the Index, Correlation coefficient by Spearman, $\mathrm{pH} / \mathrm{KCl}$, sediment, water reservoirs

Changes in properties of sediments have been going on for a long time. The most intensive ones have been happening since the beginning of industrial development, intensive burning of fossil fuels, mining of mineral resources and the beginnings of using agrochemicals in agriculture (Lahučký et al., 2009). Potentially toxic elements have markedly affected sedimentation of the environment (Nguyen et al., 2005; Khun et al., 2008; Peng et al., 2009; Enfeng et al., 2010; Hiller et al., 2010). Their toxic influence in sediments is not demonstrated visually at once. However, gradual increase of their content causes indirect changes, which result in consequent degradation of sediment and the surrounding ecosystem. Chemical content of sediments also plays an important role. In addition, chemical character of individual elements and especially their relationship to sedimentation properties, their solubility or efficiency to immobilize, usability in agriculture and their input into organisms are of big importance, too (Birch and Olmos, 2008). Easily soluble elements are accepted by organisms. If solid binding between the risk factor and sediment occurs, it has low toxicity. However, gradual accumulation and reaching certain critical toxic levels result in hardly removable defects in organism occuring even in short time periods. Distribution of elements in sediments is affected by different factors such as:

1. density of high-energy binding sites on the surface,

2. strength of metal bond to sedimented phase,

3. increase of each component in sediments,

4. chemical characteristics of water phase $(\mathrm{pH})$,

5. concentration of elemental macro components (Vojteková and Krakovská, 2006).
Contamination of sediment itself, especially in the surface layer, has grown proportionally due to gravitation in relation to the intensification and chemicalisation of diverse industrial and agricultural production (Tang et al., 2008). Detoxication of sediments by technical means is very limited in comparison with detoxication of hydrosphere and atmosphere. Self-cleaning ability of sediments is low or none as well as self-cleaning ability of the air and water. It is necessary to realize that toxicity of potentially toxic elements is not a permanent function. When these toxic elements enter sediments, physical-chemical changes occur and such elements participate in geochemical cycle. It results in the appearance and disappearance of a whole sequel of matter, which either increases or decreases toxicity of a particular element in the environment. The above mentioned important parametres play a significant role in the evaluation process of mobility and bio accessibility of elements in the environment. However, in general we must eliminate the evaluation types of neither antropogenic contamination nor geogenes contamination. Many authors claim that value of exchange reactions in soil as one of the most important parameters influences especially the content of risk elements in the bio accessible form as well as sorption parameters of sorbents. Their selectivity over sorption of elements is diverse in different areas of $\mathrm{pH}$ (Makovníková et al., 2006). An explanation of this phenomenon is based on the correlation between charges of soil sorbents and values of soil reaction. A potentially toxic element can have relatively low sorption of toxic metal at low value of $\mathrm{pH}$ due to the competition for sorption sited by the protons $\mathrm{H}^{+}$. Such 
$\mathrm{pH}$ values diversely influence the mechanism of sorption of potentially toxic metals in various $\mathrm{pH}$ regions, e.g. proton competition is the most important process in the acid region of $\mathrm{pH}$ (Makovníková et al., 2006). We can conclude that in most cases the adsorbed components are released if $\mathrm{pH}$ of the particular environment is decreased (Bradl, 2005; Peng et al., 2009). Acid pH (pH less than 7) causes a release of the risk elements from the ferric and carbonate complexes. Rapid decomposition of organic matter of sediments bound with potentially toxic elements leads to an increased salinity, and consequently soluble organic complexes with metals arise (Peng et al., 2009). Potentially toxic elements adversely affect the surrounding environment as well as health of humans and organisms, in particular (Dercová et al., 2005). Environmental degradation defined by varied degree of degradation within particular individual regions has negative impact on human health, life span and the quality of ecosystems at all (Lahučký et al., 2009). This study focuses on an analysis of sediments of selected water reservoirs of Piargs group. Its aim is to determine values of exchange reactions in soil of these sediments. Based on the results gained by chemical analysis we aim to predict possible adverse effects on the environment. Taking into account the environment, we also aim to determine correlation, statistical significance of dependencies of analysed environmental parameters.

\section{Material and methods}

The status of the monitored areas has been assessed based on the observation and chemical analysis of sediments from selected water reservoirs in the Banská Štiavnica territory. A statistical analysis was performed by "Indices Analysis" (Obtulovič, 2010) and "Spearman's rank correlation coefficient" (Stehlíková, 1999). Sediment samples were taken once a year in autumn during the period from 2001 to 2010 from the selected water reservoirs. The only exception was the reservoir of Windšachta in 2002, which was drained out due to its reconstruction at that time. Exploitation of sediments was carried out by using a sink-hole technique from the wet bottom. Samples were taken mainly with a hand sampler from a part of the bank. The weight of all samples was up to $5 \mathrm{~kg}$. Samplings were carried out from a dam sediment and from the settled sediments located opposite the dam. In 2002, the samplings from the water reservoirs Počúvadlo, Malá and Vel'ká Richňava were taken from the depth of $3.0 \mathrm{~m}$, $5.0 \mathrm{~m}$ and 8.0 meters using a submersible digger launched from a boat. An analysed sample represents five samplings from one sampling location, while the sample material was mixed in clean polyethylene containers. Sediment samples were homogenised and dried at $40{ }^{\circ} \mathrm{C}$ under bulbs during the period of 48 hours. The samples were subsequently grounded into fine-textured soil by a soil mill (VEB Thurm ZG 1). To determine the content of the analysed elements (As, $\mathrm{Cd}, \mathrm{Cu}, \mathrm{Hg}, \mathrm{Pb}, \mathrm{Zn}$ ), a sedimental fractionation with the texture under $0.125 \mathrm{~mm}$ has been used. Analysis of samples in leachate was carried out according to existing legislative measures. Two different methods, the flow electrochemical method and the atomic absorption spectrometric method have been used to analyse chemical elements in leachate. The analysis of samples in leachate to find out values of exchange reactions in soil was carried out by the machine "pH meter - JENWAY 3510". It was calibrated on 3 point $\mathrm{pH}$ calibration (buffer) ( $\mathrm{pH} \mathrm{4,7,9).} \mathrm{The} \mathrm{values} \mathrm{of} \mathrm{exhange}$ reaction in soil were determined by potentiometry in aqueous suspension and in $1 \mathrm{~mol} \mathrm{dm}^{-3}$ from the solution $\mathrm{KCl}$ according to the methodology by Fiala et al. (1999).

\section{Results and discussion}

The main feature of a large part of the Štiavnica range is that it is built mainly from tertiary volcanic rocks which were converted by hydrothermal activity. The sulphate weathering of rocks leads to oxidation of sulphite and subsequent release of $\mathrm{H}_{2} \mathrm{SO}_{4}$. It results in reduction of values of soil reaction. This fact is also confirmed by the results of $\mathrm{pH}$ measurement in the areas of interest $(\mathrm{pH} / \mathrm{KCl} 3.68-5.52)$. These areas are situated in the region of hydrothermally converted volcanic rocks. In our case, exchange soil reactions in sediments ranged from 5.6 to 7.2 during the period 2001-2010 in the Banská Štiavnica territory (Table 1). Bonds of particular contaminants are changed in relation to the changes of physical and chemical properties of sediments. Subsequently, their migration abilities or properties of toxicology are changed. $\mathrm{pH}$ is a key parameter in the evaluation of mobility and bio accessibility of elements in the environment (Barančíková, 1998; Makovníková et al., 2006). Most of the risk elements intensely migrate in the environment, when $\mathrm{pH}$ is under 7. Depending on the conditions of sedimentation, potential contaminants are accumulated mainly in places of poor water circulation and places of high amounts of fine-textured clayey sediments containing high contents of organic matter (Urminská, 2010).

The most significant difference in $\mathrm{pH}$ was recorded in the period 2002-2003 (value of the difference was 0.8) and from 2008 to 2009 (0.82). The significant change of $\mathrm{pH}$ was recorded in the periods 2001-2002 (value of the difference was 0.62), 2007-2008 (0.75) and 2009-20010 (0.44) in the reservoir of Počúvadlo. The values of the difference were 0.6 during the period 2001-2002, 0.66 in 2005-2006, 0.82 in 2008-2009, 0.69 in 2009-2010 in the water reservior Windšachta. Significant figures of values of the difference in $\mathrm{pH}$ were recorded for the location Velká Richňava in the period 2008-2009 (0.55) and

Table 1 Values of exchange reactions in sediment in the selected water reservoirs during the period from 2001 to 2010

\begin{tabular}{|l||c|c|c|c|c|c|c|c|c|c|}
\hline & $\mathbf{2 0 0 1}$ & $\mathbf{2 0 0 2}$ & $\mathbf{2 0 0 3}$ & $\mathbf{2 0 0 4}$ & $\mathbf{2 0 0 5}$ & $\mathbf{2 0 0 6}$ & $\mathbf{2 0 0 7}$ & $\mathbf{2 0 0 8}$ & $\mathbf{2 0 0 9}$ & $\mathbf{2 0 1 0}$ \\
\hline $\mathbf{P}$ & 5.98 & 6.6 & 6.4 & 6.7 & 6.71 & 6.48 & 6.71 & 5.96 & 5.99 & 6.43 \\
\hline MR & 6.2 & 5.6 & 5.94 & 5.6 & 5.72 & 6.38 & 6.6 & 6.64 & 5.82 & 6.51 \\
\hline VR & 6.52 & 6.5 & 6.12 & 6.61 & 6.60 & 6.87 & 6.62 & 6.65 & 7.2 & 6.67 \\
\hline W & 6.9 & 6.7 & 5.9 & 6.88 & 7.01 & 6.7 & 6.71 & 7.00 & 6.91 & 6.7 \\
\hline
\end{tabular}

P - water reservoir Počúvadlo, MR - Malá Richňava, VR - Vel'ká Richňava, W - Windšachta 
during the period 2009-2010 (0.53). For the water reservior Windšachta, the calculated values were up to 0.8 in the period 2002-2003 and 0.31 during the period 2009-2010. Therefore, even a little change of $\mathrm{pH}$ may cause dramatic effect on the specification of the elements. Narrow range of $\mathrm{pH}$ is quite a common feature of water reservoirs. Their $\mathrm{pH}$ ranges from 4 to 9 due to the carbonate buffer system and local geological conditions. Many ways of element movement (such as complexation, adsorption/desorption, coagulation, biological uptake and their opposite processes) are very dependent on $\mathrm{pH}$. It has been scientifically proven that $\mathrm{pH}$ has significant effect on the specification of chemical elements and thus directly affects the bio accessibility and the potential toxicity of metal contaminants. Accumulation of certain waste products and spoil heaps left in the mining areas, where a large concentration of the sulfate and microorganisms occur, may lead to the formation of highly acidic leachates known as acid rock drainage. These side effects of mining produce a large concentration of sulfuric acid, which have ability to dissolve metals and influence the quality of water from surface and ground water resources as well as agriculturally productive soil. The amount of contamination of water is often difficult to quantify ideally in water, because contamination may be transient and it also occurs in different iterations. For this reason, sediments are good long-term indicators of contamination. Contaminants that enter the water reservoir are captured in the backwaters and from the time perspective, accumulation is longer and their concentration increases. Water in sediments, often called interstitial water or porewater also plays an important role when determining migration of contaminants among water column, sediment and cycle of the contaminants within sediment (Ritter et al., 2002). The observed results show that the concentration of arsenic ranged from 0.22 to $0.481 \mathrm{mg} \mathrm{kg}^{-1}$ in dry matter, the concentration of cadmium ranged from 0.22 to $22.60 \mathrm{mg} \mathrm{kg}^{-1}$ in dry matter, the concentration of copper was from 1.66 to $14.0 \mathrm{mg} \mathrm{kg}^{-1}$ in dry matter, the concentration of mercury from 0.018 to $0.49 \mathrm{mg} \mathrm{kg}^{-1}$ in dry matter, the concentration of lead $8.20-59.04 \mathrm{mg} \mathrm{kg}^{-1}$ in dry matter and the concentration of zinc ranged from 6.8 to $98.0 \mathrm{mg} \mathrm{kg}^{-1}$ in dry matter. The mobility of cadmium and its bio accessibility has the highest value of $\mathrm{pH}$ in an acidic medium of sediments as it ranged from 4.5 to 5.5. On the other hand, cadmium is less mobile in alkaline medium. It has a tendency to precipitate on the surface of clay minerals if its value of $\mathrm{pH}$ is in alkaline medium. Mobility of cadmium is controlled by solubility of $\mathrm{CdCO}_{3}$ or $\mathrm{Cd}_{3}\left(\mathrm{PO}_{4}\right)_{2^{\prime}}$, if value of $\mathrm{pH}>7.5$. Solubility of lead is decreased by increased values of $\mathrm{PO}_{4}^{3-}$. Lead has high affinity to clay minerals of illitesmectite type in acidic medium but its afinity to the formation of organic complexes is increased if it is in a carbonate area. Solubility of copper compounds is at the lowest within $\mathrm{pH}$ range from 7 to 8 . If copper has $\mathrm{pH}$ lower than 7 , dominated ions are $\mathrm{CuOH}^{+}$and $\mathrm{Cu} 2(\mathrm{OH})_{2}{ }_{2}^{2+}$. On the other hand, if value of $\mathrm{pH}<8$, organic complexes of copper are formed. The factors which control the mobility of zinc are similar to the ones for cadmium and copper. Adsorption of zinc is affected by two mechanisms; it is cation exchange capacity which happens in acidic medium. On the other hand, in alkaline medium it is chemisorption which is dependent on the presence of organic ligands. lon of $\mathrm{Zn}^{2+}$ and compounds of $\mathrm{ZnSO}_{4}$ are dominant in the acidic medium, ions and compounds of $\mathrm{ZnHCO}_{3}$ and
$\mathrm{ZnCO}_{3}$ are dominant in alkaline medium (Barančíková, 1998; Makovníková et al., 2006; Urminská, 2011). According to Khun et al. (2008), individual elements are generally more mobile in the acidic reaction of specific medium. This fact is also claimed by another author (Bradl, 2005). The generally accepted rule is that potential accessibility of potentially toxic elements is in inverse proportionality to the value of soil reaction (Čréry et al., 2007). The acidic pH of environment is found in areas, affected by intensive anthropogenic activity and mining activity (mining ores containing sulfur - pyrites, galena). This state is often accompanied by the pollution of atmosphere, e.g. $\mathrm{SO}_{2}$, which is formed from burning of fossil fuels. Due to the fact that potentially risky elements can be significantly toxic even at less concentration and a large part of them may be accumulated in living organisms, their presence in sediments can pose potential risk of negative changes to the quality of the environment. To conclude, according to the Index analysis observation of the development of average $\mathrm{pH}$ values in our sampling locations in relation to the monitored period from 2001 to 2010 show the values of moderate dynamics (Figure 1). The most significant index values have been found in the water reservoir Počúvadlo in 2008. They were decreased by $11.18 \%$ compared to the year 2007 and index values were increased by $10.37 \%$ in 2002 compared to 2001. For the location Malá Richňava, the index values were decreased by $12.35 \%$ in 2009 compared to 2008 , the index values were increased by $11.86 \%$ in 2010 compared to 2009 . In addition, significant index values have been found in the water reservoir Vel'ká Richňava in 2010. They were decreased by $7.36 \%$ compared to the year 2009 and index values were increased by $8.27 \%$ in 2009 compared to 2008 . Moreover, index values with the decrease of $11.94 \%$ in 2003 compared to 2002 and index values with an increase of $16.61 \%$ in 2004 compared to 2003 were observed in the water reservoir Windšachta. According to the calculated indices of dependencies, the development of values of exchange reactions in soil can be evaluated as moderately dynamic and potentially negative for the environment due to an increase in percentage of values in all observed sampling locations during the monitored period.

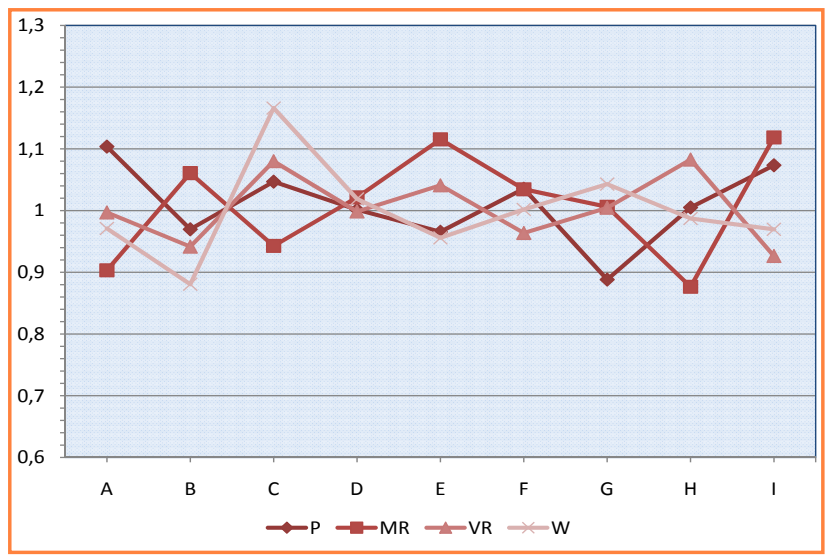

Figure 1 Value indices for $\mathrm{pH}$ in Počúvadlo, Malá Richňava, Vel'ká Richňava, Windšachta for the years from 2001 to 2010

P - water reservoir Počúvadlo, MR - Malá Richňava, VR - Velká Richňava, W - Windšachta; A - calculation for the years 2001/2002, B - 2002/2003, C - 2003/2004, D - 2004/2005, E - 2005/2006, F - 2006/2007, G 2007/2008, H - 2008/2009, I - 2009/2010 
Table 2 The Spearman coefficients - relationship between $\mathrm{pH} / \mathrm{KCl}$ and selected elements for years 2001 to 2010

\begin{tabular}{|l||c|c|c|c|c|c|}
\hline \multicolumn{1}{|c|}{} & $\mathbf{A s}$ & $\mathbf{C d}$ & $\mathbf{C u}$ & $\mathbf{H g}$ & $\mathbf{P b}$ & $\mathbf{Z n}$ \\
\hline \hline $\mathbf{p H} / \mathbf{K C l}$ & $-0.54358(1)$ & 0.94161 & 0.91630 & 0.39598 & 0.37181 & -0.15456 \\
\hline $\mathbf{2 0 0 1}$ & $0.4564(2)$ & 0.0584 & 0.0837 & 0.6040 & 0.6282 & 0.8454 \\
\hline $\mathbf{p H / K C l}$ & 0.36812 & 0.01507 & 0.25897 & -0.34475 & 0.41501 & -0.62263 \\
\hline $\mathbf{2 0 0 2}$ & 0.2953 & 0.9670 & 0.4700 & 0.3293 & 0.2330 & 0.0545 \\
\hline $\mathbf{p H} / \mathbf{K C l}$ & -0.56861 & -0.72102 & -0.10888 & -0.88108 & -0.82559 & -0.57643 \\
\hline $\mathbf{2 0 0 3}$ & 0.4314 & 0.2790 & 0.8911 & 0.1189 & 0.1744 & 0.4236 \\
\hline $\mathbf{p H / K C l}$ & 0.44280 & 0.42835 & 0.12025 & -0.31651 & 0.24269 & -0.77602 \\
\hline $\mathbf{2 0 0 4}$ & 0.5572 & 0.5716 & 0.8798 & 0.6835 & 0.7573 & 0.2240 \\
\hline $\mathbf{p H / K C l}$ & 0.47092 & 0.08595 & 0.49167 & -0.48406 & 0.38883 & -0.49644 \\
\hline $\mathbf{2 0 0 5}$ & 0.5291 & 0.9141 & 0.5083 & 0.5159 & 0.6112 & 0.5036 \\
\hline $\mathbf{p H / K C l}$ & 0.32628 & -0.11725 & 0.8958 & -0.21622 & -0.08475 & -0.09499 \\
\hline $\mathbf{2 0 0 6}$ & 0.6737 & 0.8828 & 0.7104 & 0.7838 & 0.9152 & 0.9050 \\
\hline $\mathbf{p H / K C l}$ & -0.77334 & -0.29662 & 0.31622 & $-0,23601$ & 0.45993 & -0.44481 \\
\hline $\mathbf{2 0 0 7}$ & 0.2267 & 0.7034 & 0.6838 & 0.7640 & 0.5401 & 0.5552 \\
\hline $\mathbf{p H / K C l}$ & 0.73572 & 0.71974 & 0.61267 & 0.57016 & 0.78512 & 0.98185 \\
\hline $\mathbf{2 0 0 8}$ & 0.2643 & 0.2803 & 0.3873 & 0.4298 & 0.2149 & 0.0182 \\
\hline $\mathbf{p H / K C l}$ & 0.75911 & 0.79829 & 0.50161 & -0.37183 & -0.10237 & 0.11683 \\
\hline $\mathbf{2 0 0 9}$ & 0.2409 & 0.2017 & 0.4984 & 0.6282 & 0.8976 & 0.8832 \\
\hline $\mathbf{p H / K C l}$ & 0.73789 & 0.39927 & 0.61883 & 0.57738 & 0.40571 & -0.01355 \\
\hline $\mathbf{2 0 1 0}$ & 0.2621 & 0.6007 & 0.3812 & 0.4226 & 0.5943 & 0.9865 \\
\hline
\end{tabular}

(1) the Spearman coefficient, (2) level of significance

Based on this, the comprehensive results' assessment shows that the calculated indices of dependencies report temporal ariability. The arithmetic average of indices for each year for Počúvadlo reached 1.009. For Malá Richňava it was 1.008, for Velká Richňava 1.004 and for Windšachta the value reached 0.999. The development is highly dynamic and reacting to the environment, because water reservoirs are affected by chemical and physical factors (e. g. potentially toxic elements, $\mathrm{pH})$. The dynamic and varied state confirms geochemical nature of the chemical elements and associated $\mathrm{pH}$.

These findings may be particularly assumed due to the intensive anthropogenic activity and the change of thermodynamic and hydrological conditions. The occurence of this phenomenon is also recorded in some calculated index values of water reservoirs. Thermodynamic and hydrological conditions were effected by e.g. water management and recreational activities, the local conditions at the place of sampling (dry and flood periods, technical instruments used for sampling and the sampling of material) (Urminská, 2011). Dynamic change of $\mathrm{pH}$ in the environment may cause significant release of parts from chemical elements as well as release of potentially toxic elements from sediments into the ecosystem. This can result in contamination of water ecosystems and their surroundings. The Spearman's rank correlation coefficient $\left(\rho_{s}\right)$ is a measure of dependence based on the measurement of the correlation between rankings (Stehlíková, 1999). The Spearman coefficients - correlation between $\mathrm{pH} / \mathrm{KCl}$ and selected elements for years 2001 to 2010 are shown in table 2 .

The year 2008 was the most significant one in relation to the calculated correlation of $\mathrm{pH}$ and potentially toxic elements. The value of Spearman's rank correlation coefficient for concentration of dependencies between $\mathrm{pH}$ and $\mathrm{Zn}$ is 0.98185 . Spearman's coefficient is highly significant at the 0.05 alpha level $\left(p_{\text {value }} 0.0182<0.05\right)$. A given dependence is a positive dependence, which means there is an increased concentration of $\mathrm{Zn}$ with an increased concentration of $\mathrm{pH}$ in the environment. The mobility of $\mathrm{Zn}$ is affected by many factors such as $\mathrm{pH}$, granularity of material, content of organic matter in observed medium, binding with oxides and hydroxides, and also by content of mineral salts. The detected chemical anomalies in the environment in relation to a given element show prevailingly dispersed nature and elements are bound on the urban and industrial agglomerations (Bodiš and Rapant, 1999). Salminen et al. (2005) state that detected concentration of $\mathrm{Zn}$ is associated with chemical elements, in particular $\mathrm{Cd}, \mathrm{S}, \mathrm{Pb}$ and $\mathrm{Cu}$, and shows strong positive correlation with $\mathrm{Pb}, \mathrm{Cd}$. However, it shows a weak correlation with $\mathrm{As}, \mathrm{Hg}, \mathrm{Ba}$ and $\mathrm{P}_{2} \mathrm{O}_{5}$. It points to the combined impact of mineralization, anthropogenic activities, mining, metallurgy and the impact of effluents from the urban agglomerations as well (Salminen et al., 2005). Zinc is significantly toxic for organisms in sediments and aquatic environment (Kafka and Punčochářová, 2002) and on the other hand, zinc is a major essential element for agriculturally cultivated plants. The soluble forms of zinc are easily uptaken by plants and its increase of value is linear with a concentration in the nutrient solutions and soil (Ďurža and Khun, 2002). Deficit of this element is manifested degeneratively especially on the young plants and an excess amount of zinc in nutrition can be detrimental to the biochemical control systems.The resulting effect of chemical elements is individual in the specific 
environment and depends on many factors and properties. Environmental problems arise when risk elements become easily accessible for organisms (Urminská et al., 2013). Industry and mining of non-renewable resources form significant sources of toxic contamination of surface water, sediments and groundwater. Industrial and mining contamination may enter the aquatic environment by atmospheric transport emissions which are subsequently deposited directly by dry or wet deposition into surface water or may also be deposited indirectly by flush and leaching of soil deposits. Regional and vertical variability of the concentration of risk elements in the mineral deposits must be considered alongside with an assessment of contamination caused by chemical elements. Even though potentially toxic elements may enter the aquatic systems by weathering of minerals and rocks, local inputs as results of human activity may significantly contribute to the contamination by elements in the environment. In water and sediments, risk elements are subject of complexity of chemical and biochemical reactions, which influence their chemical changes and disposition between different phases. Their interactions affect a lot of processes including exchange reactions, adsorption or desorption processes and oxidation-reduction reactions, volatility and physical advection. Altogether, these transformation processes are key factors affecting distribution, environment, bio acessibility and influences of elements in aquatic systems. Transport and ways of contamination in water and sediments are strongly influenced by the form of element in the solution. A lot of complexes of elements occur in inaccessible forms in the environment for a long period of time and consequently they are competitors to the forms of bioacessible contaminants in processes in the target environment. Potentially toxic elements in the compounds can transform, merge or transport so that their bioaccessible part of the total concentration of contaminant is reduced during the change process. Other important chemical processes such as reduction processes have potential to change accessible concentration in the aquatic systems. Particularly, both values of exchange of soil reaction and activity of hydrogen ions are significant factors which influence movement of potentially toxic elements in the aquatic environment. These factors have very significant effect on the chemical-physical state of elements. Divergence, or overrun of values of geochemical background signalise the need to deal with diagnosis related to potential risk of increased contents of elements (Khun et al., 2008; Liu et al., 2008; Tang et al., 2008; Hiller et al., 2010; Wei et al., 2010).

\section{References}

BARANČÍKOVÁ, G. 1998. Návrh účelovej kategorizácie pol'nohospodárskych pôd Slovenska z hladiska ich citlivosti k znečisteniu tažkými kovmi. In Rostlinná výroba, roč. 44, 1998, č. 3, s. 117-122.

BIRCH, G. F. - OLMOS, M. A. 2008. Sediment-bound heavy metals as indicators of human influence and biological risk in coastal water bodies. In ICES J of Mar. Sc., vol. 65, 2008, no. 8, pp. 1407-1413.

BODIŠ, D. - RAPANT, S. 1999. Geochemický atlas SR. Čast' VI.: Riečne sedimenty, Bratislava : MŽP SR a GSSR, 1999. 145 s. ISBN 80-88833-18-3.

BRADL, H. B. 2005. Heavy metals in the environment: origin, interaction and remediation. London : Elsevier LTD, 2005. $282 \mathrm{p}$. ČÉRY, J. - TÓTH, T. - MELICHÁČOVÁ, S. - TIMORACKÁ, M. 2007. Stanovenie rizikových prvkov v pôdach lokalít Brekov a Dunajská
Streda využitím SSE podla Ziehena a Brümmera. In VII Rizikové faktory pot. retazca, Nitra: SPU, 2007. s. 37-41.

ENFENG, L. - Jl, S. - LIYUAN, Y. - ENLOU, Z. - XIANGHUA, M. JIANJUN, W. 2010. Assessment of heavy metals contamination in the sediments of Nansihu Lake catchment, China. Env. Monit \& Assess., 2010. 161, pp. 217-227.

DERCOVÁ, K. - MAKOVNÍKOVÁ, J. - BARANČíKOVÁ, G. - ŽUFFA, J. 2005. Bioremediácia toxických kovov kontaminujúcich vody a pôdy. In Chemické listy, 2005, 99, s. 682-693.

ĎURŽA, O. - KHUN, M. 2002. Environmentálna geochémia niektorých taažkých kovov. Bratislava : Skr. PRIF UK Bratislava, 2002. $116 \mathrm{~s}$. FIALA, K. 1999. Záväzné metódy rozborov pôd. Čiastkový monitorovací systém - pôda. Bratislava : VÚPOP Bratislava, 1999. $142 \mathrm{~s}$.

HEGEDÜSOVÁ, A. - HEGEDÜS, O. - MUSILOVÁ, J. 2006. Riziká kontaminácie pôd kadmiom. Nitra: UKF, 2006. $89 \mathrm{~s}$.

HILLER, E. - JURKOVIČ, L. - ŠUTRIEPKA, M. 2010. Metals in the surface sediments of selected water reservoirs, Slovakia. In Bull. of Eniron. Contam. and Toxic., 2010. pp. 635-640.

KHUN, M. - ĎURŽA, O. - MILIČKA, J. - DLAPA, P. 2008. Environmentálna geochémia. Bratislava : Geo-grafika2008. $278 \mathrm{~s}$. LAHUČKÝ, L. - ÁRVAY, J. - BYSTRICKÁ, J. - ČÉRY, J. 2009. Obsah t’ažkých kovov $v$ polnohospodárskej produkcii dopestovanej $v$ metalicky zataženom regióne Slovenska. In Agricult., 2009, 55, s. 156-163.

LIU, H. - LI, L. - YIN, CH. - SHAN, B. 2008. Fraction distribution and risk assessment of heavy metals in sediments of Moshui Lake. In J of Environm. Scien. (Elsevier), 2008. 20, pp. 390-397.

MAKOVNÍKOVÁ, J. - BARANČíKOVÁ, G. - DLAPA, P. - DERCOVÁ, K. 2006. Anorganické kontaminanty $v$ pôdnom ekosystéme. In Chemické listy, 2006, 100, s. 424-432.

NGUYEN, H. L. - LEERMAKERS, M. - OSÁN, J. - TÖRÖK, S. - BAEYENS, W. 2005. Heavy metals in lake Balaton: water column, suspended mater, sediment and biota. In Sc. of the Tot Environ., 2005, 340, pp. 213-230. OBTULOVIČ, P. 2010. Bioštatistika. Nitra: SPU Nitra, 2010. s. 139-141. PENG J. F. - SONG, Y. H. - PENG, Y. - CUI, X. - QIU, G. 2009. The remediation of heavy metals contaminated sediment. In Journal of Hazard. Mat., vol. 161, 2009, no. 2/3, pp. 633-640.

RITTER, L. - SOLOMON, K. - SIBLEY, P. - HALL., K. - KEEN, P. MATTU, G. - LINTON, B. 2002. Sources, pathways and relative risks of contaminants in surface water and groundwater. In J of Tox. Environ. Health, 2002, pp. 1-142.

SALMINEN, R. (CHIEF-EDITOR) - BATISTA, M. J. - BIDOVEC, M. DEMETRIADES, A. - DE VIVO, B. et al. 2005. Geochemical Atlas of Europe. Part 1 - Background Information, Methodology and Maps. Brussels : EuroGeoSurveys Belgium, 2005. 525 p.

STEHLÍKOVÁ, B. 1999. Biometrika (Terminologický slovník). Nitra : SPU, 1999. $95 \mathrm{p}$.

ŠUTRIEPKA, M. 2006: In:<http://www.banskeodpady.sk/files/ Michal\%20\%C5\%A0utriepka.pdf)>.

TANG, CH.W. - IP, C. CH. - ZHANG, G. - SHIN,P. K. S. - QIAN, P. - LI, X. 2008. The spatial and temporal distribution of heavy metals in sediments of Victoria Harbour, Hong Kong. In Marine Poll. Bulletin, $5^{\text {th }}$ Conference on Marine Pollution and Ecotox., 2008, no. 7, pp. 816-825.

URMINSKÁ, J. 2010. Potenciálny vplyv vybraného geochemického prostredia na zdravotný stav detskej populácie v oblasti Žiarskej kotliny. Nitra : SPU, 2010.80 s.

URMINSKÁ, J. 2011. Riziko vplyvu vybraných tažkých kovov $v$ sedimentoch sledovaných bansko-štiavnických vodných nádrží na životné prostredie. In Habilitačná práca, Nitra : SPU, 2011. 177 s. URMINSKÁ, J. - ONDRIŠÍK, P. 2013. Frakcionácia zinku zo sedimentov metódou selektívnej sekvenčnej extrakcie. In Agrochémia, 2013, č. 2 , s. 6-10

VOJTEKOVÁ, V. - KRAKOVSKÁ, E. 2006. Frakcionačná analýza sedimentov - limitácie selektivity sekvenčného lúhovania. In Chemické listy, 2006, 100, s. 1096-1104.

WEI, M.R. - JIANG, Y.H. - ZHAO, W.Y. - JIANG, C.F. - LONG, M.F. 2010. Heavy Metals Pollution Assessment of Surface Sediment in Dananhu Lake. In J of Guilin Univ. of Technology, 2010, 30, pp. 415-418. 